\title{
PORNOGRAFIA E LITERATURA: UMA HISTÓRIA PELO BURACO DA FECHADURA
}

\section{PORNOGRAPHY AND LITERATURE: A STORY BY THE KEYHOLE}

\author{
Natanael Duarte $A Z E V E D O$ (UFRPE) \\ José Temístocles FERREIRA JÚNIOR (UFRPE)
}

\begin{abstract}
Resumo: A presença da pornografia na literatura passa a ser considerada como categoria a partir do século XIX através de suas qualidades formais, que criam possibilidades de análise que abrangem a intencionalidade da inserção do texto pornográfico e/ou a sua funcionalidade nos gêneros literários. $\mathrm{O}$ objetivo de nossa pesquisa é compreender o discurso pornográfico nos jornais da Belle époque brasileira e a sua relação com a história da literatura por meio da pornografia e da política. Nosso corpus é formado por colunas que tratavam de questões pornográficas no jornal $O$ Rio $N u$ (1898-1916), além de outros impressos que mantiveram um diálogo direto com o jornal, a saber: O Riso (1911-1912), O Coió (19011902) e $O$ Nabo (1900). Os resultados de nossa análise mostram que, através dos instrumentos da sátira e os diferentes modos de apropriação da pornografia, é possível perceber que a esta estava a serviço da crítica política, além do seu caráter inerente que é a excitação do leitor.
\end{abstract}

Palavras-chave: Pornografia. Jornal $O$ Rio Nu. Política. História da literatura.

\begin{abstract}
The presence of pornography in literature is considered as a category since the nineteenth century for its formal qualities, which makes possible analyses to comprehend the intentionality of the insertion of pornographic text and/or its functionality in the literary genres. We aim at understanding the pornographic discourse of $O$ Riso and its relation with the history of literature by means of the pornography and politics. We analyzed columns that deal with pornographic and other newspapers that had a direct dialogue with $O$ Rio $N u$ (1898-1916) such as $O$ Riso (1911-1912), O Coió (1901-1902) and $O$ Nabo (1900). The results of our analysis show that, by means of satire instruments and the different ways of appropriation of pornography, it is possible to see that the political criticism used pornography and, also, its inherent character that is the reader's excitement.
\end{abstract}

Keywords: Pornography. Newspaper $O$ Rio Nu. Politics. Literary history.

\section{Considerações iniciais}

\footnotetext{
Não há livros morais ou imorais, apenas livros bem ou mal escritos - Oscar Wilde em "O retrato de Dorian Gray".

Imperioso, colérico, arrebatado, em tudo extremado, de um desregramento na imaginação sobre os costumes que não teve equivalente nesta vida, em duas palavras, eis-me aqui: matai-me ou me aceiteis assim, pois não mudarei [...]. Se, como dizeis, minha liberdade terá de pagar o preço do sacrifício de meus princípios ou de meus gostos, podemos dizer-nos um eterno adeus, pois antes sacrificaria mil vidas e mil liberdades, se as tivesse.

(Carta do Marquês de Sade a sua esposa em setembro de 1783)
} 
O academicismo árido, mesmo nas Ciências Humanas e Sociais, não conseguiu fazer silenciar um tema tão controverso como a pornografia. Porém, os estudos que circulam pelas instâncias de consagração do discurso (FOUCAULT, 1996) têm uma certa dificuldade, em especial, nos estudos da Literatura, para teorizar ou construir proposições de análises de obras que carregam em si o estigma de literatura menor e/ou inferior por tratar de temas que envolvem a sexualidade explícita.

É bem verdade que muito se produziu no que diz respeito a antologias eróticas e/ou pornográficas, mas com breves comentários e pequenas indicações metodológicas. Para citarmos alguns exemplos, temos duas traduções de obras consideradas clássicas da literatura pornográfica: Sonetos luxuriosos, de Pietro Aretino (2011), com tradução, nota biográfica e um curto ensaio crítico realizado por José Paulo Paes; Teresa Filósofa, Anônimo do século XIII (2000), com Prefácio de Renato Janine Ribeiro. Como exemplo de produção luso-brasileira, temos antologias como: Que seja em segredo, escritos da devassidão nos conventos brasileiros e portugueses dos séculos XVII e XVIII, reunidos por Ana Miranda (2014), no qual a pesquisadora explora de forma breve o contexto de produção dos poemas e suas temáticas, tais como: os tormentos do corpo, a contemplação da mulher amada, a solidão, a musa libertina, os abismos do amor, os sonhos e as fantasias eróticas; em Antologia pornográfica, de Gregório de Matos e Glauco Matoso, poemas reunidos por Alexei Bueno (2004), também há uma breve introdução na qual o pesquisador tenta situar a relevância dos autores em suas épocas, além de destacar o apagamento linguístico de termos considerados chulos e construir um glossário para entendermos o sentido sexual dos termos utilizados pelos poetas. No que diz respeito às pesquisas acadêmicas que resistiram à aridez academicista em relação aos estudos do erotismo e da pornografia, podemos citar os trabalhos de Corbin (2008), Dabhoiwala (2013), Macclintock (2010), Moraes (2013) e Vainfas (2014).

A título de apagamento da literatura pornográfica, gostaríamos de exemplificar com uma publicação de livro de poesias que antecedia a produção de nossos jornais em um curto tempo de menos de uma década. Quase no mesmo período em que circulou o jornal $O$ Rio $N u$, foi publicado no Brasil um livro de poesias, intitulado “Obras Poéticas Livres” (1882) ${ }^{1}$, que

1 Segundo Fábio Frohwein de Salles Moniz (2012), a biografia de Laurindo é permeada por controvérsias, uma vez que não há unanimidade pelos estudiosos da história da literatura e pelos críticos literários acerca da grafia correta do nome de Laurindo como também sobre as datas de suas publicações. Moniz (2012) afirma que a única obra publicada em vida foi Trovas (1853). Os outros livros foram organizados a partir de poemas, lunduns e modinhas espalhadas nos periódicos de Oitocentos, a exemplo da Marmota Fluminense (1857). Ainda segundo Moniz (2012), Laurindo faleceu em 28 de setembro de 1864, ou seja, dezoito anos antes da publicação póstuma de seu livro de poemas pornográficos. 
explorava as mesmas temáticas da sedução, fornicação, prostituição, defloramento de jovens, entre outros, por Laurindo José da Silva Rebello².

DECIMA

Certa mulher de um marquez

Fodi por cousa nenhuma,

Mas fodi sómente uma,

Deus me livre de outra vez!

A tal putinha me fez

Na porra ${ }^{3}$ tal desatino,

Com seu rebolar malino

Poz-me a mente tão corrupta

Que julguei no cú da puta

Encontrar o palatino! (REBELLO, 1882, s/p)

Vale destacar que o referido poeta foi Patrono da Cadeira 26 da Academia Brasileira de Letras e mesmo assim a sua obra caiu no esquecimento da história da literatura, vindo a ser lembrado apenas por suas trovas e suas publicações na Marmota Fluminense (1857), segundo Moniz (2012). Para produção de suas poesias pornográficas, Rebello não utilizou nenhum pseudônimo, como era comum à época, mesmo em se tratando de literatura pornográfica. De acordo com Barbosa (2007, p. 32), em seus estudos sobre a história da literatura e da leitura nos jornais oitocentistas luso-brasileiros ${ }^{4}$, "observa-se uma tendência forte ao anonimato", mas essa configuração de autores/editores anônimos e/ou a utilização de pseudônimos vem de além-mar. Assim como acontecia nas publicações brasileiras (que tendiam a imitar os jornais europeus, em especial, ingleses e franceses), os editores da Europa utilizavam este recurso do anonimato/pseudônimo para se prevenir das punições legais ou por não ter importância o nome do autor, "talvez porque a prevalência seja a da palavra escrita e não daquele que escreve" (BARBOSA, 2007, p. 35). Para Barbosa, ainda sobre o cenário da imprensa brasileira de oitocentos, “parece ser menos um 'fraqueza' ou 'defeito' [...] do que uma marca da linguagem jornalística no século XIX”, (2007, p. 32).

2 No que diz respeito à outra controvérsia, a grafia do nome de Laurindo, deparamo-nos com dois modelos gráficos: na impressão do livro de 1882 está grafado o sobrenome "Rebello", já na biografia de Moniz (2012) e no cadastro da Academia Brasileira de Letras (ABL), a grafia do sobrenome é "Rabelo". Optamos pela primeira escrita na tentativa de mantermos a fidelidade do texto fonte que tivemos acesso.

3 De acordo com o Dicionário de termos eróticos e afins, organizado por Horácio de Almeida (1981), o significado de "porra" pode ser o membro viril (pênis ereto) ou o esperma. No contexto do poema de Rebello, o significado que melhor se enquadra é o primeiro, pênis ereto.

$4 \mathrm{O}$ estudo empreendido por Barbosa (2007) diz respeito à imprensa luso-brasileira do século XIX, mas como bem apontou em sua pesquisa, essa realidade da materialidade e a configuração do impresso dizem muito do cenário Ocidental. Não restringimos, portanto, nossa análise ao contexto dos jornais luso-brasileiro, mas também dos livros. 


\section{A pornografia de mão em mão no Brasil oitocentista: $A$ História de Cada Uma: serões do convento}

No mesmo período de fim do século XIX, circulou “um 'clássico' do gênero [romances para homens]" (EL FAR, 2004, p. 15), o romance pornográfico A História de Cada Uma: serões do convento, assinada pelo pseudônimo de Rabelais, que narra as experiências sexuais de freiras, contadas pelas próprias personagens. Dedicaremos esse espaço a uma explanação para exemplificar o tipo de literatura pornográfica que circulava no fim do século XIX e início do $\mathrm{XX}$, em meio à clandestinidade e ao anonimato, pois "para os autores, a clandestinidade supõe naturalmente o anonimato, ou o recurso a pseudônimos" (MAINGUENEAU, 2010, p. 93).

A narrativa inicia com a abadessa e noviças rememorando os atos sexuais e se permitindo ao gozo. A história se passa na véspera do dia de São João com as freiras reunidas na casa do recreio para contar as suas aventuras sexuais:

Como sabeis, cada uma de nós vai contar a primeira aventura galante da sua existência, aquela que deu pelo menos quebra ao cabaço, porque, como deveis concordar, o signo de Virgo é coisa que não existe no nosso sistema conventual. (RABELAIS, s/d, p. 4)

O romance pornográfico é dividido em 11 capítulos, a saber: "O passado de uma abadessa", "Uma freira modelo", "História da Clarinha: ao que leva à curiosidade", "História de D. Violante: guardar uma mulher", "História de D. Margarida: quadros realistas contra a virtude", "História de D. Angélica: o que uma menina viu e fez... até os 15 anos", "História de D. Guilhermina: ver é bom, gosar é melhor", "História de D. Virginia: quadros defesos", "História de D. Cecília: a mocidade de uma noviça", "História de D. Delfina: virgem!” e, por fim, o último capítulo: "Conhecimentos antigos". Este último se divide em 4 partes que caminham para o arremate da narrativa, findando o dia de véspera de São João após as mais voluptuosas histórias narradas, culminando em um apogeu do desejo. Primeira parte, "Conhecimentos antigos": D. Margarida ao sair da casa do recreio na manhã de 23 de junho de 18... se depara com o novo hortelão que estar a cuidar dos craveiros. A freira empolga-se com o robusto homem e é revelado ao leitor que se trata de Manoel, seu antigo amante e pai de sua filha. Ao final do encontro, eles marcam às onze da noite para conversarem e se entregarem aos prazeres acumulados. Na segunda parte, "O novo capelão", chega ao convento um jovem e belo padre que aguça os mais luxuriosos desejos das freiras, em especial D. Margarida que toma para si a missão de seduzir o capelão. Na terceira parte, "Entre noviças": as religiosas se queixam que estão a tempos satisfazendo-se umas com as outras, fazendo às vezes do homem. Cogitam então seduzirem o capelão e o hortelão. De imediato, D. Margarida tenta subverter Revista Graphos, vol. 19, n² 2, 2017 | UFPB/PPGL | ISSN 1516-1536 
esse plano, alegando que mais cedo tentara seduzir o hortelão, mas não conseguira êxito. Apesar da tentativa de despistar as irmãs em relação à sedução do hortelão, as religiosas tomadas de desejos luxuriosos armam um plano para arrebatar Manoel, o hortelão, e padre Francisco, o novo capelão. Na quarta e última parte, “Às onze da noite”: D. Margarida disposta a não dividir o "cetro" de seu amado com as outras freiras decide contar-lhe os planos de sedução de D. Delfina. Após fecharem a porta da cela de D. Margarida, entregam-se às mais lúbricas ações de gozo até o cair da madrugada. A narrativa encerra com a descrição da cópula e do tesão acumulado de três anos entre Manoel e D. Margarida.

Mesmo para traçarmos um perfil da literatura pornográfica brasileira que circulou em impressos de final dos Oitocentos, precisamos recorrer a um contexto ocidental mais amplo que trate de jornais e livros pornográficos europeus, uma vez que há uma clara influência destes na composição dos impressos brasileiros. Sendo assim, trabalhamos com três obras acadêmicas que se propuseram a construir a história da pornografia na literatura ocidental e uma possibilidade de análise de obras pornográficas. Porém, gostaríamos de ressaltar que tanto Alexandrian (1993), como Hunt (1999) e Goulemot (2000) dedicaram seus estudos apenas ao contexto europeu, principalmente à literatura francesa e à inglesa, consideradas pelos estudiosos como o berço da literatura pornográfica.

A partir desses pressupostos, a fim de restaurar o apagamento da literatura pornográfica brasileira, causada pelo hiato deixado pelos historiadores da imprensa e da literatura, propomonos a construir uma breve história da literatura erótica dos trópicos pelo buraco da fechadura da imprensa da Belle Époque, por meio do periódico O Riso. Interessa-nos nessa construção da história resgatar os sentidos dos termos utilizados para os romances pornográficos, além de indicarmos alguns livros do gênero, que circularam no Brasil de fim do século XIX e início do XX.

Assim, nossa pesquisa pode contribuir com "outros modos de ler e de fazer circular a literatura e a cultura" (BARBOSA, 2007, p. 24), além de trabalhar em prol do preenchimento da lacuna de uma historiografia da literatura mais ampla, como destaca Zilberman (2003, s/p): “Ainda não foi completada a história que narra a dívida da literatura brasileira para com o jornalismo, especialmente no século 19."

5 ZILBERMAN, Regina. Literatura de rodapé: reedição de folhetim esquecido oferece novas pistas a estudiosos. Disponível em: $\quad$ http://jbonline.terra.com.br/papel/cadernos/ideias/2003/11/07/joride20031107009.html > . Acessado em 15/07/2015.

Revista Graphos, vol. 19, n² 2, 2017 | UFPB/PPGL | ISSN 1516-1536 


\section{O Rio nu: um jornal pornográfico de longa vida}

O jornal $O$ Rio $N u$ circulou no Brasil durante os anos de 1898 e 1916, com sede editorial na cidade do Rio de Janeiro. Durante os 18 anos de circulação bissemanal (duas vezes por semana) o jornal estampava em sua capa gravuras eróticas e humorísticas.

Em seu primeiro ano, sob a direção de Heitor Quintanilha, Gil Moreno e Vaz Simão, com sede no Largo de São Francisco, $n^{\circ}$ 6, o jornal era composto por quatro páginas, sem imagens, mas com textos voltados para o humor por meio da pornografia, como podemos observar nas seções do Quadro 3, abaixo:

\section{Quadro 1 - Seções do jornal $O$ Rio $N u 1$}

\begin{tabular}{|c|c|c|c|c|}
\hline Discurso & Seção & Número & Ano & Página \\
\hline Pornográfico & $\begin{array}{c}\text { "Ellas querem..." } \\
\text { por Lucas Tavares } \\
\text { e } \\
\text { "Perguntas e } \\
\text { Respostas" }\end{array}$ & 2 & 1898 & p. 3 \\
\hline Humorístico & $\begin{array}{c}\text { "Cartas de Amor" } \\
\text { "Em casa de } \\
\text { Cocottes" } \\
\text { e } \\
\text { "As prégas" }\end{array}$ & 2 & 1898 & p. 1 \\
\hline Político-social & "Semana despida" & 2 & 1898 & p. 1 \\
\hline
\end{tabular}

As seções do segundo número do jornal, apresentadas acima, representam a composição de um impresso que iniciava um modo de se produzir jornal por meio do discurso pornográfico e humorístico. Além das seções voltadas para discussões políticas e sociais, por meio do discurso humorístico e pornográfico, o impresso trazia seções comuns a todos os jornais, tais como: divulgação do jogo do bicho, resultados do sorteio da loteria, críticas teatrais, charadas, anúncios de produtos e serviços e programação cultural (em especial, havia a divulgação de peças de teatro). Antes de $O$ Rio $N u$, eram produzidos livros com a temática pornográfica, mas de acordo com os registros da Biblioteca Nacional do Rio de Janeiro, segundo pesquisas realizadas em campo, não há registros de jornais mais antigos que trouxessem em sua proposta editorial o tema da pornografia.

No que concerne à feitura do jornal em relação à comunidade leitora, o jornal $\mathrm{O}$ Rio $\mathrm{Nu}$ apresenta em sua seção "Semana Despida" a seguinte representação dos leitores: 
Foi $<$ mais a mim! $><$ mais a mim! $>$. Homens, mulheres, velhos, moços, moças, um delirio! Os velhos e velhas, então parece que descobriram neste jornal caustico uma espécie de sequardina e não tiveram mãos a medir.

Alguns velhos vi em que compraram o jornal sexta-feira á noite e no sabado pela manhã acordaram com formidáveis olheiras.

Excesso de leitura forad'horas. (O Rio Nu, Rio de Janeiro, 21/05/1898, Num. 2, Anno. I, p. 1 - grifos nossos)

O impresso se volta para uma comunidade leitora geral (homens e mulheres, jovens ou moços, velhos ou velhas), não ficando restrito apenas aos homens, como era esperado para a época, pois a leitura do romance não era apropriada para as mulheres, considerada uma atitude inaceitável para damas da sociedade (Cf. EL FAR, 2007), muito menos o contato com os romances ou demais textos com temática pornográfica. Mas, segundo $O$ Rio $N u$, na citação acima, o jornal se apresentava, por meio do humor, como um instrumento de excitação e masturbação, conforme podemos ver no trecho: "Os velhos e velhas, então parece que descobriram neste jornal caustico uma espécie de sequardina e não tiveram mãos a medir" ( $O$ Rio $N u$, Rio de Janeiro, 21/05/1898, Num. 2, Anno. I, p. 1). De acordo com a definição do dicionário Aulete On Line, a sequardina significa um "extrato da secreção testicular utilizada em opoterapia"6, ou seja, há uma referência aos fluídos sexuais.

Os editores de $O$ Rio $N u$ concluem a seção "Semana Despida" com uma resposta aos moralistas que se opunham à feitura e à circulação do jornal: "E venham para cá os moralistas, venham, que verão o troco que levam" ( $O$ Rio $N u$, Rio de Janeiro, 21/05/1898, Num. 2, Anno. I, p. 1). Dessa forma, podemos inferir que, se por um lado havia uma expectativa de horizonte com uma comunidade leitora generalizada, por outro, havia a consciência e o deboche voltado para uma parcela da sociedade que era contra a circulação de obras e jornais pornográficos.

Com o passar dos anos, o periódico foi desenvolvendo suas técnicas de impressão e, com a chegada de novas prensas mais modernas (Cf. SODRÉ, 2011), O Rio Nu amplia a quantidade de páginas, seções e insere mais imagens no jornal.

A partir do sexto ano, número 469, de 03 de janeiro de 1903, sob direção agora de $\mathrm{J}$. Moraes \& C., com sede na Rua da Assembleia, nº. 94, O Rio Nu passa a ser composto de oito páginas e passa a receber imagens em sua capa. Nos números anteriores, as imagens vinham dispostas no decorrer do jornal, mas não havia imagem como tema na capa. É bem verdade que no ano de 1903 o jornal apresenta imagens em suas capas, mas ainda em preto e branco e por meio de desenhos, ou gravuras. Esse modelo tipográfico se mantém até a década de 1910. De

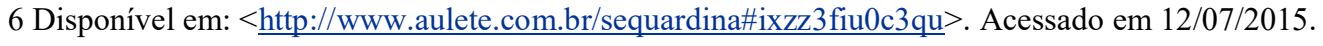


acordo com Sodré (2011), esse período é marcado pela modernização de tipografias, além do "enriquecimento" da imprensa, juntamente com a ascensão burguesa brasileira, num período considerado a Belle Époque tropical.

Um pouco antes, ainda em 1908, $O$ Rio $N u$ estampa pela primeira vez uma fotografia na capa, no número 1.036, de 13 de junho, mas esse recurso tipográfico não se mantém em todos os números, havendo uma oscilação entre fotografias (em número bem reduzido) e gravuras (maioria dos exemplares).

A partir do número 1.283, de 2 de novembro de 1910, O Rio $N u$ estampa definitivamente em sua capa a fotografia de uma mulher nua em destaque. A opção pela modernização tipográfica dá a entender que os proprietários preocupavam-se em atrair mais leitores pela qualidade editorial, sem precisar aumentar o valor do jornal, que era vendido ao preço de 100 réis o número avulso.

As seções do número 1.283 fazem críticas à política da época, governo de Hermes da Fonseca, dividindo o espaço no jornal com seções voltadas para o humor e a temática pornográfica. Assim como era de costume na miscelânea que eram os jornais, esses textos, ora políticos ora pornográfico-humorísticos, dividiam o espaço do papel com outros gêneros, principalmente, a propaganda de produtos/serviços e livros pornográficos.

A presença de uma fotografia erótica na capa de um impresso representava, ao mesmo tempo, uma inovação e uma ousadia à época (1910), e isso, de certo modo, trouxe influências para o outro jornal: $O$ Riso. Tal fato pode ser constatado pelos aspectos tipográficos de $O$ Riso, que se apropria dessa prática e lança no ano de 1911 um jornal que se caracteriza pela impressão de fotografias de atrizes e dançarinas francesas em suas capas. Vale destacar que só após novembro de 1910 a capa do jornal $O$ Rio $N u$ aparece definitivamente com fotografia erótica e o mesmo modelo tipográfico com fotografias de mulheres nuas adotado por $O$ Riso data de maio de 1911, ou seja, seis meses após a primeira publicação com fotografia de $O$ Rio $N u$. Nas publicações semanais de $O$ Rio $\mathrm{Nu}$, a prática de publicar fotos de mulheres nuas se mantém até o ano de 1916.

Vale salientar que, apesar da ampla circulação e produção de material impresso pornográfico, com textos, fotografias, charges e publicidade erótica como vimos nessa "influência" de $O$ Rio $N u$, a prática de produção de materiais pornográficos não era vista com "bons olhos" pela censura da época.

O período de circulação do jornal, final de século XIX e início do XX, foi marcado pela censura policial e médica em torno da discussão acerca da sexualidade. Mesmo não 
havendo uma lei explícita que punisse os responsáveis pela circulação de material pornográfíco e os compradores de material "proibido", El Far (2007. p. 289) destaca que "o Código Penal Republicano (1891), por sua vez, não fazia menção explícita à produção e disseminação de obras pornográficas, limitando-se, de modo genérico, a punir possíveis atentados ao pudor e ofensas públicas", mas a censura pelo viés da moralidade era frequente, pois a influência do catolicismo português ainda era muito forte no Brasil, fato esse que marca o século XIX como o período mais "hipócrita" da história brasileira (Cf. DEL PRIORI, 2011).

Por mais que não houvesse uma punição legal (EL FAR, 2007), a leitura de livros e jornais pornográficos era vista de forma enviesada pela sociedade de transição de século XIXXX. Mas essa censura (se podemos chamar assim, uma vez que não houve uma investigação e punição severa) não era para todos da sociedade que consumiam os produtos pornográficos. As "grandes vítimas" dessa comunidade leitora foram as mulheres, seja por sua exclusão do mercado editorial pornográfico - os gêneros literários pornográficos eram explicitamente voltados para os homens ("leitura só para homens", "romance para homens", "leitura para homens", "contos para velhos" eram expressões comumente usadas para se referir aos textos pornográficos) - seja pela "fragilidade mental" que era atribuída às mulheres pelos médicos e religiosos de oitocentos.

\footnotetext{
Como o próprio termo sugere, os enredos que recebiam tal subtítulo deveriam ser proibidos às mulheres, vistas naquela época como pessoas de personalidade frágil, por isso, suscetíveis aos encantos da narrativa. Entregues a essas histórias, as leitoras poderiam se esquecer das convenções sociais e sair em busca de emoções e afetividades distantes de sua realidade. Os homens, de modo diferente, por serem capazes de discernir o mundo da ficção do cotidiano das regras e dos bons costumes, não corriam o mesmo risco. Por isso, tinham acesso irrestrito a essas leituras. (EL FAR, 2007, p. 290)
}

Porém, vale lembrar que essa afirmação é sobre os títulos das obras pornográficas, pois, como bem observou Michel de Certeau (2012), o leitor é dotado de astúcias para desviar e subverter as normas sociais em nome da prática de leitura. Mas as mulheres não eram as únicas reprimidas em relação à leitura de romances pornográficos. Aos homens restavam as punições físicas. Segundo as pesquisas médicas de fim de século XIX (EL FAR, 2007), os homens que liam romances "proibidos" poderiam desenvolver algum mal na saúde, como: doenças sexualmente transmissíveis (a divulgação de produtos para cura da sífilis e da gonorreia eram frequentes nos jornais oitocentistas), debilidade mental, desgaste físico, anemia, entre outras.

Os homens, por sua vez, deveriam evitar o estilo de vida celibatário, quer dizer, o cotidiano de bailes, festas e de namoros efêmeros. Esse tipo de comportamento não representava apenas uma recusa aos ideais do casamento e da família, como 
provocava também o crescimento de casos de aborto, infanticídio, prostituição e de doenças sexualmente transmissíveis. Nessa perspectiva médica, o corpo sofria inevitavelmente uma enorme debilidade, tornando-se fraco, impotente e "gasto". A disseminação dessas idéias no final de oitocentos era tão eficaz que o romance intitulado Um homem gasto (1885), assinado pelo pseudônimo L. L., rapidamente ganhou espaço nas colunas da crítica literária daquele período. Tratava-se do drama de um rico brasileiro, recém-casado, que, em resposta aos anos de libertinagem, viase impedido de consumar seu casamento. Nas palavras publicadas num jornal, faltavalhe o "essencial para as funções matrimoniais" (A Semana, 9/5/1885). Desesperado, o protagonista, "já gasto”, procurava a ajuda dos médicos para remediar sua situação. Depois de provar em vão reagentes e medicamentos, o herói enlouquecia e, em seguida, cometia o suicídio (L.L., 1885). Além de possuir cenas provocativas, Um homem gasto, anunciado como um "romance para homem", assim como Amar, gozar e morrer..., parecia acreditar nos preceitos científicos propagados na época. (EL FAR, 2007, p. 301)

Uma instituição pública se destacou no século XIX para o tratamento das "vítimas" da leitura pornográfica: Instituto Philippe Pinel, antigo Hospício de Pedro II. Os males decorrentes da leitura e da prática dos prazeres da carne eram associados à demência mental, principalmente no caso das mulheres (Cf. FACCHINETTI, 2008).

O ano de inauguração da primeira colônia de alienadas data de 1911, segundo Facchinetti et al $(2008$, p. 235) - fato este que coincide com o ano da primeira publicação de $O$ Riso -, "a primeira colônia feminina só foi fundada em 1911, ao passo que duas das colônias masculinas já estavam em funcionamento desde 1887”. Nesse mesmo período, há uma ação governamental, comandada por Juliano Moreira, voltada para o encarceramento de mulheres, pois o número de internas por problemas mentais havia aumentado, informação que corrobora o comentário de El Far (2007) acerca da fraqueza das mulheres em relação à leitura dos romances pornográficos.

Em 1911, o Ministério da Justiça e Negócios Interiores reorganiza a Assistência a Alienados. Juliano Moreira, já renomado por seu trabalho no Hospício Nacional, é nomeado Diretor Geral de Assistência a Psicopatas (Alienados). Neste mesmo ano, o Decreto 8.834, de 11 de junho, cria a Colônia de Alienadas (Psicopatas) do Engenho de Dentro com o objetivo inicial de receber pacientes indigentes do sexo feminino que seriam transferidas do Hospício Nacional de Alienados. Novamente o motivo principal da criação da colônia é a superlotação de mulheres pobres no Hospício Nacional. A Colônia é localizada em terreno cedido pela Marinha, em local onde existiam pavilhões para tratamento de portadores de beriberi, sendo realizada a troca por um terreno no Andaraí. Neste terreno será construído, mais tarde, o atual Hospital do Andaraí. O primeiro diretor da Colônia de Alienadas do Engenho de Dentro foi o Dr. Simplício de Lemos Braule Pinto. A princípio foram feitas algumas poucas adaptações no estabelecimento existente para receber cerca de 200 pacientes. Entretanto, no ano seguinte (1912), foi realizada uma ampliação geral de todos os serviços, construindo-se um novo pavilhão para receber mais 200 mulheres. (RAMOS \& GEREMIAS, s/d, s/p) ${ }^{7}$

7 RAMOS, Fernando A. da Cunha \& GEREMIAS, Luiz. Instituto Philippe Pinel: origens históricas. Disponível em: $<$ http://www.sms.rio.rj.gov.br/pinel/media/pinel_origens.pdf>. Acessado em 09/07/2015.

Revista Graphos, vol. 19, n² 2, 2017 | UFPB/PPGL | ISSN 1516-1536 
Uma associação comum que se fazia a esses gêneros pornográficos era a prática da masturbação ou o desvio da ordem da procriação (Cf. ROUDINESCO, 2008), castigada por meio da culpabilização do pecado (Cf. DELUMEAU, 2003), mas que com a medicina mental do século XIX recebe outra conotação, segundo Roudinesco (2008), e assume o status de doença - é uma patologia, não mais um desvio dos preceitos religiosos.

Um nome que muito influenciou a medicina mental do século XIX foi Krafft-Ebing. O médico desenvolveu uma extensa pesquisa sobre a sexualidade, publicada no livro Psicopatia Sexual (1879), no qual o autor desenvolveu um estudo acerca dos desejos sexuais, buscando responder às questões da prática sexual desviante - e por isso patológica -, influenciando os estudos posteriores sobre a sexualidade. Segundo Corrêa (2006, p. 85), "foi sem dúvida KrafftEbing quem mais influenciou o estudo da sexualidade no final do século passado".

Mesmo nas publicações posteriores à publicação de Krafft-Ebing (como, por exemplo, Três ensaios sobre a sexualidade, de Freud, em 1905), havia menção ao receio da masturbação como uma deficiência ou perecimento do indivíduo: "Não quero que meus dois filhos... ('em conseqüência da masturbação', cabe sem dúvida acrescentar aqui, partindo dos pensamentos oníricos) pereçam" (FREUD, [1905]/1989, s/p) ${ }^{8}$.

Nesse cenário de "ataque" às práticas sexuais e à publicação de obras pornográficas, instauram-se os jornais pornográficos que, como mencionou Sodré (2011), foram produzidos em todo o território brasileiro, mas tiveram pouca circulação. Vimos que, em se tratando de circulação de jornais pornográficos, $O$ Rio $N u$ rompe com esse paradigma, uma vez que se firma como um jornal de "longa vida", 18 anos, com duas publicações por semana. No mesmo caminho seguiu $O$ Riso, que mesmo tendo circulado apenas por dois anos, destacou-se no cenário da imprensa nacional com a periodicidade ininterrupta e com a utilização dos mais modernos recursos de impressão para divulgar além dos temas pornográficos, uma crítica “ácida" contra o governo republicano.

O diálogo entre os dois jornais não se restringia apenas ao seu enfrentamento às questões políticas republicanas e à temática pornográfica, por meio do discurso humorístico. $\mathrm{O}$ editor do jornal $O$ Rio Nu publicou em sua seção "Boas Festas" as felicitações enviadas pela redação de O Riso. Essa prática de fazer felicitações nos jornais era comum, seja pela divulgação de alguma notícia ou em datas comemorativas, seja pela divulgação de textos publicados pelos

8 Disponível em: $\quad<$ http://www.psicanaliseflorianopolis.com/artigos/147-obras-completas-de-sigmundfreud.html $>$. Acessado em 09/07/2015.

Revista Graphos, vol. 19, n² 2, 2017 | UFPB/PPGL | ISSN 1516-1536 
colaboradores dos jornais. Outro jornal que interagiu com $O$ Rio $N u$, em sua época de circulação, 1901-1902, foi $O$ Coió, que era de propriedade de Rebello Braga, futuro dono de $O$ Riso. O diálogo entre $O$ Coió e $O$ Rio $N u$ era representado pela divulgação do livro de Carlos Eduardo (Bock), “A Vingança de um Sapateiro”, que foi colaborador de O Rio Nu por muitas edições, tanto com contos quanto com romances, mas havia se mudado para redação de $O$ Coió no ano de 1902.

\section{A pornografia desnudada: apropriações do termo pornografia nos jornais pornográficos}

Nessa seção dedicada à pornografia, abordaremos alguns temas que são relevantes para análise dos jornais pornográficos de 1898 a 1912. Como alguns discursos presentes nos jornais da Belle Époque são (re)vividos de outra época, como o discurso pornográfico dos séculos XVIII, revisitaremos algumas obras dessa época com o fito de situarmos a origem dos jornais pornográficos oitocentistas.

Para conduzir a nossa breve arqueologia, apresentamos algumas variações de expressões utilizadas pelos jornais eróticos para apresentação de obras pornográficas. Expressões como: "romances para serem lidos com uma mão", "romances joviais", "romances para homens" e "literatura alegre" eram comumente utilizadas para divulgação de livros, álbum de fotografias e romances folhetins com a temática pornográfica. Era por meio das referidas expressões que o leitor identificava um tipo específico de literatura: romances, poesias e arte pornográfica.

No que diz respeito à expressão "romances para serem lidos com uma mão", sua origem data do século XVIII e permanece até o final de XIX, representando bem a produção literária que tinha como objetivo despertar os desejos mais íntimos do leitor. Segundo Goulemot (2000), essa expressão foi usada por Rousseau (2011) no século XVIII, em suas Confissões, para se referir a certos "livros perigosos". Os "livros perigosos" citados por Rousseau (2011) englobavam romances, tratados filosóficos, textos políticos e textos licenciosos, uma vez que o filósofo apontava tais obras como responsáveis por despertar a curiosidade e o desejo do leitor. 


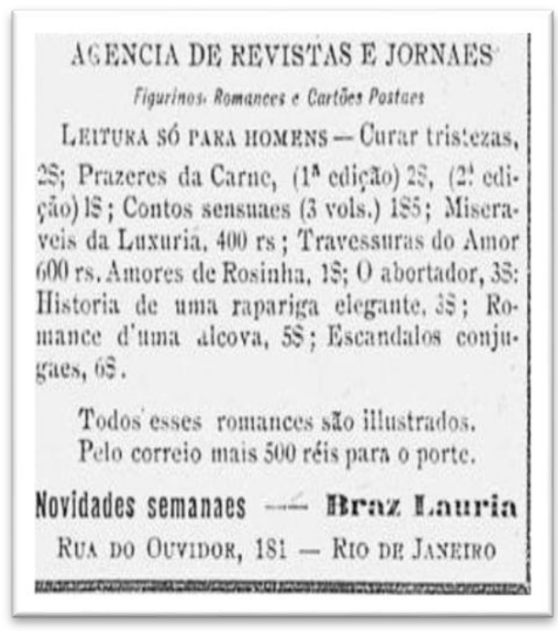

Figura 1 - Leitura só para homens

Fonte: (O Rio Nu, Rio de Janeiro, Num. 1.340, Anno XIV, p. 5, em 24/05/1911)

"Prazeres da Carne", "Contos sensuaes", "Miseraveis da Luxuria”, "Travessuras do Amor", "Amores de Rosinha", "O abortador", "História de uma rapariga elegante", "Romance d'uma alcova" e "Escandalos conjugaes" são alguns exemplos dos títulos que circulavam em 1911 e estavam à venda no escritório do jornal O Rio $N u$. Tais romances eram impressos com imagens eróticas a fim de atrair o leitor, segundo o próprio jornal: "Todos esses romances são illustrados" (O Rio Nu, Rio de Janeiro, Num. 1.340, Anno XIV, p. 5, em 24/05/1911).

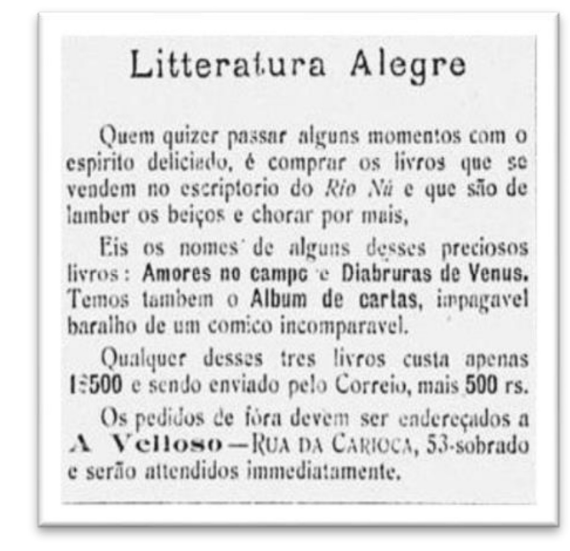

Figura 2 - Literatura Alegre

Fonte: (O Rio Nu, Rio de Janeiro, Num. 1.303, Anno XIV, p. 4, em 11/01/1911)

De acordo com o anúncio do jornal $O$ Rio $N u$, de 11 de janeiro de 1911, por meio da "Litteratura Alegre", o leitor pode passar "momentos com o espirito deliciado [...] e que são de lamber os beiços e chorar por mais" (O Rio Nu, Rio de Janeiro, Num. 1.303, Anno XIV, p. 4, em 11/01/1911). Alguns títulos são: "Amores no campo", "Diabruras de Venus" e "Album de 
cartas". Este último não se trata de um romance, mas de um "impagavel baralho de um comico incomparavel" (O Rio Nu, Rio de Janeiro, Num. 1.303, Anno XIV, p. 4, em 11/01/1911). Além dos romances pornográficos, era muito comum as tipografias venderem e anunciarem nos jornais álbuns de fotografia, cartas e postais eróticos.

Já a expressão "romance para homens" foi bastante utilizada no século XIX tanto para se referir aos livros pornográficos que eram divulgados nos jornais como para intitular o romance folhetim com temática erótica. Consideravam-se também os álbuns de fotografia que traziam atrizes nuas em suas páginas.

Como podemos ver no jornal $O$ Rio $N u$ (Rio de Janeiro, Anno II, n. 119, p. 4, em 26/08/1899), a seção "Leitura para Homens" traz a divulgação de vários romances eróticos para venda. Dentre os romances, há a divulgação, por exemplo, de "Tereza Philosopha" ao custo de $6 \$ 000$, romance libertino que circula até os nossos dias. Alguns títulos explicitavam a temática pornográfica com o fito de atrair o leitor: "Memorias de uma insaciavel" ao custo de $2 \$ 000$; “Amar, Gozar e Morrer" ao custo de 4\$000 e "Julia, confidencias de uma mulher de espirito a um de seus amantes" ao custo de $2 \$ 500$. De acordo com El Far (2004, p. 191), "nesse variado rol de 'livros para homens', algumas edições procuravam explicitar seu conteúdo 'picante' através de títulos provocativos capazes de dispensar quaisquer explicações”.

Outros títulos de sucesso se dedicavam a histórias eróticas de personagens religiosos que, segundo El Far (2004, p. 191), "padres e freiras, representantes da palavra de Deus entre os fiéis na Terra, tornavam-se, sob a pena desses escritores, exímios sedutores e donos de uma sexualidade insaciável". É o caso do romance "Memórias de cada uma: serões do convento", assinado por Rabelais, que já mencionamos. Assim como, "Memorias do Frei Saturnino" ao custo de $6 \$ 000$ e "Serões do Convento - $1^{\text {a }}$ Parte e $2^{\text {a }}$ Parte" ao custo de $6 \$ 000$ cada uma. Este último título é atribuído a José Feliciano de Castilho, assinado pelo pseudônimo M.L., de acordo com Andrade (2000).

Autores portugueses figuravam a seletiva de romances pornográficos divulgadas no jornal, como é o caso de "Poesias eróticas, burlescas e satyricas", de M. M. du Bocage ao custo de $6 \$ 000$, além do romance já mencionado "Serões do convento", atribuído pelos estudiosos a José Feliciano de Castilho. De acordo com El Far (2004, p. 192-193), “a maioria dos 'romances para homens' vinham de Portugal. Ora traduzidos dos sucessos franceses, ora escritos por literatos portugueses, que teriam descoberto um filão lucrativo no mercado editorial de seu país.”. Mas os autores brasileiros também apareciam nas estantes de livros pornográficos, como, por exemplo, Laurindo Rebello, com sua "Obras poéticas", anunciado ao custo de $3 \$ 000$, uma 
vez que esse gênero já fazia parte da leitura "de sucesso", assim "esse variado reportório de obras vendidas pelas ruas do Rio de Janeiro aos poucos recebeu títulos assinados por autores brasileiros. (EL FAR, 2004, p. 193).

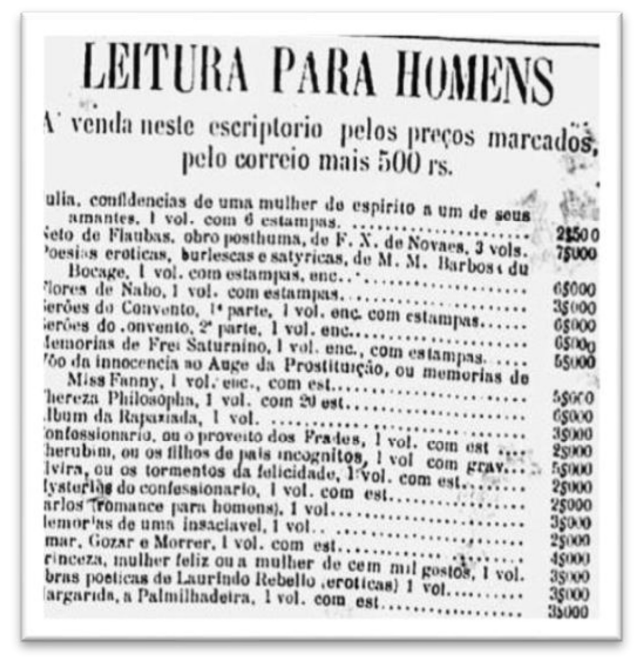

Figura 3 - Leitura para homens

Fonte: (O Rio Nu, Rio de Janeiro, Num. 119, Anno II, p. 4, em 26/08/1899)

Além dos romances em formato de livros anunciados e vendidos nos jornais, alguns romances folhetins traziam em seu subtítulo expressões que remetiam o leitor a obras pornográficas, como podemos observar o uso do termo "romance jovial" presente no jornal $O$ Riso que optou por usar essa terminologia para apresentar o seu romance folhetim erótico "As Aventuras do Rei Pausolo", leitura indicada para jovens que buscam aprender sobre as vicissitudes da vida.

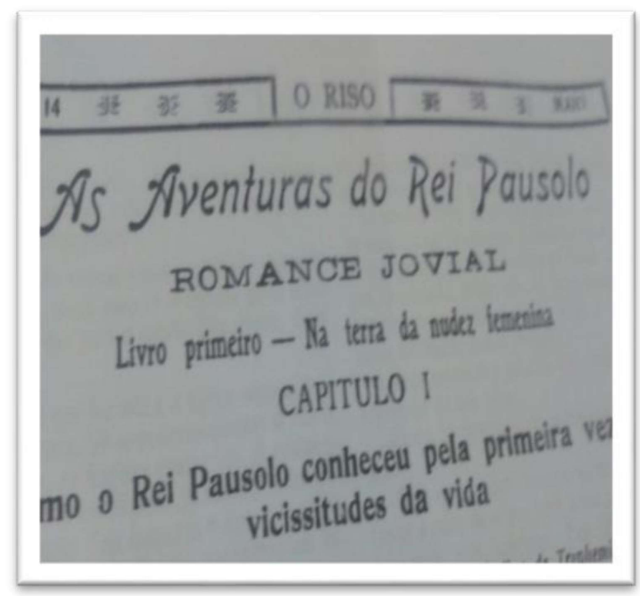

Figura 4 - Romance folhetim: "As Aventuras do Rei Pausolo" Fonte: (O Riso, Rio de Janeiro, Num. 1, Anno I, p. 14, em 26/05/1911) 
Mas esse tipo de leitura, da literatura pornográfica, não ficava restrita aos jovens, os jornais também dedicavam obras aos mais velhos, como podemos ver na divulgação do Rio Nu:

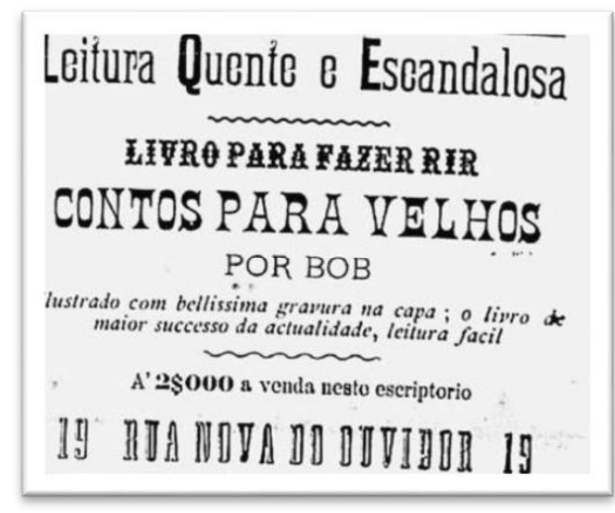

Figura 5 - Leitura Quente e Escandalosa

Fonte: $O$ Rio $N u$ (Rio de Janeiro, Num. 119, Anno II, p. 4, em 26/08/1899)

Outro termo presente nos jornais da Belle époque era "gênero alegre". Trata-se de gêneros literários que circulam em jornais (poesia, conto, crônica, romance, anedotas, charadas, caricaturas etc.) de temática humorística, mas sempre com um cunho sexual. De acordo com Schettini (2011. p. 317):

Uma das primeiras publicações a assumir o rótulo [de gênero alegre] foi Sans Dessous, que trouxe em seu número inaugural a foto dafamosa prostituta francesa Susana Castera, com a legenda: 'A iniciadora do gênero alegre no Brasil - uma justa e respeitosa homenagem de Sans Dessous.

O jornal O Coió (Rio de Janeiro, Anno II, n. 62, p. 3, em 06/01/1902) apresenta um variação do termo, intitulado como "narrativa alegre", no espaço dedicado ao folhetim, o texto “O Anselmo - Narrativa Alegre e Apimentada”, por Arduino Pimentel, que narra a história de um boêmio traído pela mulher que decide se vingar, tornando-se amante da esposa do ministro.

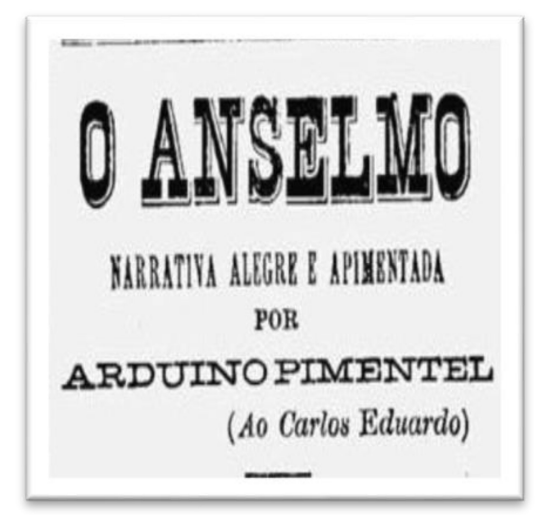

Figura 6 - Romance folhetim: O Anselmo

Fonte: (O Coió, Rio de Janeiro, Num. 62, Anno II, p. 3, em 06/01/1902)

Revista Graphos, vol. 19, n² 2, 2017 | UFPB/PPGL | ISSN 1516-1536 
Além da apropriação dos termos que designam a literatura pornográfica, os jornais pornográficos também se apropriaram de imagens muito comuns que relacionam o romance ao sexo: jovens que se entregam aos prazeres da carne pela leitura de romances.

A imagem do leitor entregue ao êxtase provocado pela leitura de alguns livros, em geral com a temática erótica, serviu de mote para representação erotizada da leitura por parte de vários artistas. Uma alegoria ${ }^{9}$ muito comum para representar a relação existente entre a leitura, o leitor e o prazer sexual pode ser visto em algumas gravuras e telas em guache desde os séculos XVI, XVII e XVIII. Geralmente esta relação é representada pela construção da figura do leitor com uma mão segurando o livro (instrumento desencadeador do desejo) e com a outra mão tocando suas partes íntimas (instrumento de obtenção do orgasmo). As mais diversas apropriações foram feitas desse tipo de imagem no decorrer dos séculos, servindo de inspiração para pintores, escritores e ilustradores, estudiosos da temática pornográfica ${ }^{10}$ e editores de jornal do final do século XIX e início do XX. Veremos mais adiante alguns exemplos de pinturas de séculos anteriores e a mesma representação do desejo sexual por meio da leitura em um jornal do século XX.

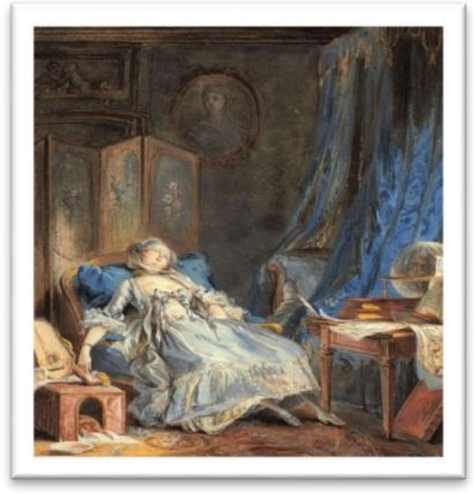

Figura 7 - La Lecture

Fonte: La Lecture (1760), por Pierre Antoine Baudoin (França, 1723-1769) ${ }^{11}$

9 Discutiremos mais a frente, em uma seção dedicada à alegoria, os conceitos que definem a alegoria e como nos apropriaremos deles para analisar os jornais.

10 Os editores, por exemplo, utilizam na capa do livro Esses livros que se lêem com uma só mão, de Jean-Marie Goulemot, a imagem Le midi, gravada por Emmanuel de Ghendt, inspirada em um guache de P. A. Baudouin, a qual representa uma mulher deitada sobre um jardim com um livro caído ao lado do seu corpo e com uma das mãos se masturbando.

11 Disponível em: <https:/www.pinterest.com/pin/105412447503913281/>. Acessado em 28/05/2015. 


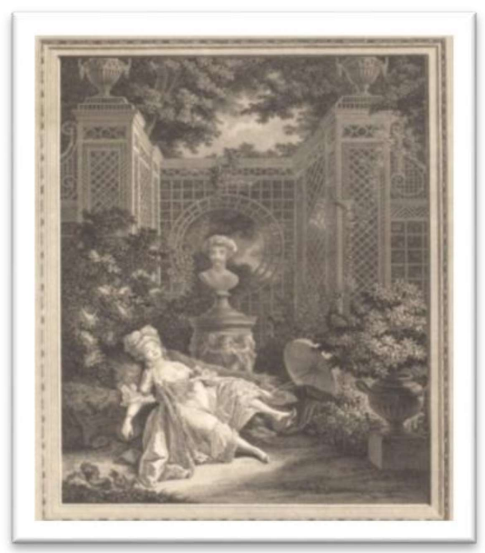

Figura 8 - Le midi

Fonte: Le Midi (1760), por Emmanuel Jean Nepomuceno De Ghendt (1738 -1815) em guache de Pierre Antoine Baudouin (1723-1769) $)^{12}$

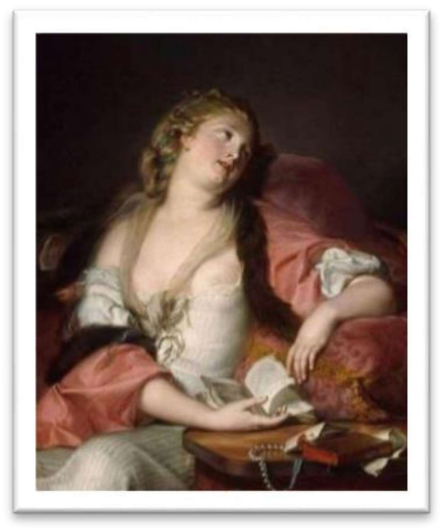

Figura 9 - Senhora lendo as cartas de Heloísa e Abelardo Fonte: Senhora lendo as cartas de Heloísa e Abelardo (1780), por Bernard D'Agesci. ${ }^{13}$

Agora veremos na capa do jornal $O$ Coió, impresso dedicado aos prazeres do riso e da carne, como a leitura era representada por meio de romances eróticos.

12 Disponível em: <https://www.artsy.net/artwork/emmanuel-jean-nepomucene-de-ghendt-after-pierre-antoinebaudouin-le-midi>. Acessado em 28/05/2015.

13 Disponível em: $<$ http://pt.slideshare.net/ladonordeste/os-livros-e-a-arte $>$. Acessado em 28/05/2015.

Revista Graphos, vol. 19, n² 2, 2017 | UFPB/PPGL | ISSN 1516-1536 


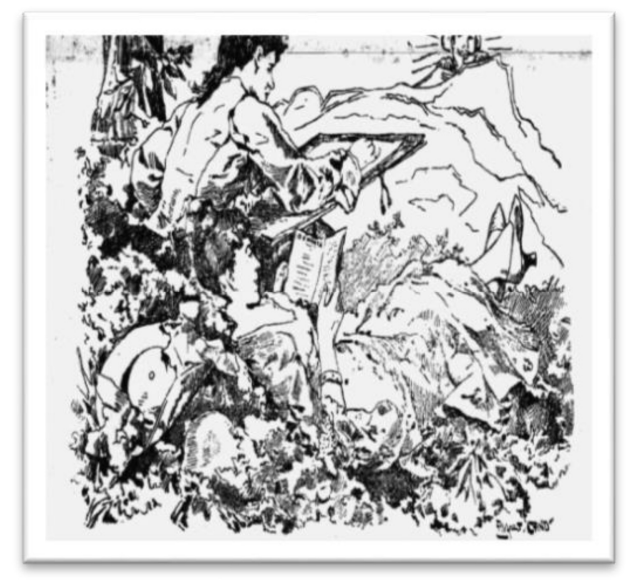

Figura 10 - Leitura Amena

Fonte: Literatura Amena ${ }^{14}$ (O Coió, Rio de Janeiro, Num. 75, Anno II, p. 1, em 24/02/1902)

Como vimos nas gravuras e pinturas acima, o tema "pornografia" circulava em diversas esferas da arte, seja na literatura, na gravura, na pintura e no jornal. Essa circulação diversificada atendia a uma variedade de consumidores, podendo ser consumida tanto pelas classes mais baixas da sociedade (a exemplo dos jornais), quanto (e principalmente) pelas camadas mais abastadas (a exemplo das pinturas), além dos livros de brochura que eram vendidos a baixo custo e, muitas vezes, traziam em sua temática a pornografia, conforme El Far (2004). De acordo com a autora, o sucesso de vendas desse tipo de impresso fez com que caísse não apenas no gosto popular como também na língua portuguesa popular:

\begin{abstract}
A ligação entre obra impressa de caráter popular e pornografia tornou-se tão forte nas décadas finais do século XIX que a encadernação em capa mole, mais conhecida como brochura, teve seu adjetivo, a palavra "brochado", logo transformado em sinônimo do órgão sexual masculino incapaz de se enrijecer durante o ato amoroso. (EL FAR, 2004, p. 201)
\end{abstract}

Apesar de a pornografia ser um tema recorrente desde os tempos áureos na literatura clássica grega e romana, como elementos de sedução, erotismo e representação física de órgãos sexuais, ela nunca foi tratada como uma categoria literária. Essa possibilidade de ser considerada uma categoria só viria a ser discutida no século XIX. De acordo com Hunt (1999, p. 10), a pornografia "não constituía uma categoria de literatura ou de representação visual independente e distinta antes do início do século XIX”.

A pornografia, na modernidade, diferentemente de sua utilização nas obras clássicas gregas e romanas, sempre esteve atrelada a outros fins como, por exemplo, à crítica e à provocação. Para Hunt (1999, p. 10): "Na Europa, entre 1500 e 1800, [a pornografia] era mais

14 Moça lendo o romance folhetim pornográfico O Empata, de Block, publicado no jornal O Coió. 
frequentemente um veículo que usava o sexo para chocar e criticar as autoridades políticas e religiosas". Ou seja, ao invés de se instaurar como uma categoria literária e preestabelecer algumas normas como ocorre com as demais categorias, a pornografia servia de meio, ou melhor, de suporte, para provocar efeitos de sentido, tais como: humor, sarcasmo, agressão, destituição de valores sociais e morais etc.

De modo geral, as categorias mais recorrentes e analisadas na literatura são: tempo (marcado pela duração da narrativa, podendo ser, por exemplo, um tempo cronológico ou psicológico); espaço (lugar em que ocorre a ação da narrativa); narrador (personagem responsável por contar a história, podendo ser em $1^{\mathrm{a}}, 2^{\mathrm{a}}$ ou $3^{\mathrm{a}}$ pessoas do discurso); personagem (pessoas ou seres personificados que vivem a ação narrativa). A pornografia, enquanto categoria, não aparece de forma fixa no texto como ocorre nas categorias citadas acima. Por essa razão, identificar o papel e a função da pornografia em uma obra literária requer a atenção do analista literário para o sentido que está por trás do constructo pornográfico, seja por meio da sátira, seja pela construção alegórica. E no caso específico do jornal oitocentista, o pesquisador deve se ater aos diálogos possíveis entre a pornografia presente nos gêneros textuais e as notícias da época.

A utilização da pornografia como "veículo para chocar e criticar" tanto podia ser feita de forma explícita como também recorria a mecanismos mais implícitos, como a alegoria. A pornografia explícita era utilizada como instrumento de ataque na ironia, enquanto que sua utilização por meio da alegoria instaura-se como elemento constitutivo da sátira, responsável pelo estabelecimento da fantasia e do ataque indireto (Cf. HODGART, 2010).

Porém, esses dois meios de utilização da pornografia, ironia e sátira, não figuram como um estilo literário acabado. A criação por meio da ironia não mantém um sentido único, haja vista a intrínseca relação entre a singularidade de um fato histórico e/ou social e a construção da ironia como efeito de sentido. Do mesmo modo ocorre com a sátira. Seria anacrônico lermos uma ironia ou uma sátira sem considerar o momento de sua enunciação. Se assim fizéssemos, estaríamos incorrendo em uma interpretação tendenciosa e deslocada de seu tempo. Visto que nas mais diversas reedições e imitações de textos que ocorriam com frequência nos séculos XVIII e XIX, as ironias e as sátiras tinham funções diferentes, pois se preocupavam sempre com o assunto de seu tempo presente. Dessa forma, a sátira de Aretino, ou aquela atribuída a Gregório de Matos, por exemplo, não podem ser tomada como modelo fixo e recorrente nas produções literárias. 
Assim, vemos que numa pesquisa que se propõe a investigar a categoria "pornografia", deve se levar em conta o momento de sua produção. Compreender o humor de Aretino ou a ousadia de Gregório de Matos, não nos garante uma análise assertiva dos romances pornográficos da Belle Époque brasileira. Muito pelo contrário, temos que nos colocar no terreno da enunciação para pensarmos numa metodologia que se alinha com os costumes e a cultura de uma dada época e assim verificar a motivação da construção da ironia ou da sátira.

Tomar a produção pornográfica como singular em sua composição nesse tipo de literatura nos faz pensar na pornografia de acordo com o que Goulemot (2000, p. 51) chamou de "lugar de trocas", ou seja, é impossível conceber a literatura pornográfica como "um conjunto homogêneo, fixo", uma vez que esta se reveste de múltiplos sentidos por meio dos procedimentos criativos que são utilizados, como o diálogo com a filosofia, a política, com a crítica social etc., tomando o tempo presente de sua composição em sua particularidade. Daí seu caráter heteróclito e multifacetado.

Segundo Goulemot (2000, p. 51) “o romance pornográfico não para de evoluir e utiliza os procedimentos do romance contemporâneo”, no século XIX, ou seja, as análises de obras pornográficas devem partir da intenção da escrita e do sentido atribuído por sua materialidade (Cf. MAC KENZIE, 2004; CHARTIER, 2011). Tal análise está longe de ser esgotada, e pesquisas desenvolvidas no âmbito da literatura, história, filosofia e áreas afins demonstram novos olhares e novas perspectivas para abordagem da temática da pornografia.

\section{Considerações finais}

Os estudos acerca da pornografia há muito têm gerado polêmica no âmbito acadêmico por sua natureza controversa, devido a sua forma (jornais e livros esquecidos pela história da literatura) e o seu conteúdo (o sexo explícito). Decidimos observar a pornografia por meio da representação de seu discurso e de sua relação com o meio político-social no jornal $O$ Rio $N u$, que circulou na Belle Époque brasileira, uma vez que entendemos que a "literatura pornográfica atua na fronteira do espaço social” (MAINGUENEAU, 2010, p. 23).

No que diz respeito aos princípios que tomamos como basilares para construção de nossa análise, tais como o conceito de pornografia e os estudos que tomam o jornal como fonte e objeto de investigação histórica, mostramos que as condições de produção do discurso, ou seja, sua enunciação, fazem-se necessárias para compreensão do discurso de uma determinada comunidade leitora de uma dada época. 
Desse modo, a pornografia deve ser vista na singularidade de sua produção de sentido, pois não há uma homogeneidade em sua composição. Muito pelo contrário, ela se reveste de múltiplos sentidos através dos mais distintos procedimentos criativos de utilização do sexo na literatura, tais como alegoria, metáforas e metonímias etc. (Cf. AZEVEDO \& FERREIRA JÚNIOR, 2016). Se tomarmos a pornografia como instrumento da sátira, precisamos compreender que tanto a sátira pode ser vista pelo ataque a um sistema de poder ou a indivíduo que o represente, como pela manutenção da ordem e da moral, por meio da arte.

Todas as particularidades observadas (a partir do pressuposto de que a enunciação do jornal deve ser vista como um discurso de uma época) indicam que o pesquisador que se propõem a analisar bens culturais, como o impresso, de um passado, deve se colocar no terreno do seu tempo de circulação a fim de evitar análises anacrônicas e descontextualizadas.

Outro fator levado em consideração em nossa pesquisa foi a necessidade de entender como o jornal $\mathrm{O}$ Rio $\mathrm{Nu}$ dialogou com outros impressos de sua época, pois, assim, seria possível compreender qual o posicionamento ideológico do jornal e a sua apropriação da pornografia como elemento alegórico responsável pela construção de uma identidade política antirrepublicana.

Com base nessa constatação, fica patente também que a pornografia cria distintos modos de produção de sentido, pois a cada situação posta no jornal, é necessário compreendermos qual o significado da pornografia naquela denúncia. Por isso, é mister nos envolver com o discurso da época em que o jornal foi produzido e circulou. As pistas da produção de sentido só aparecerão a partir do momento que reconhecermos a história e o discurso de sua época.

\section{Referências}

ALEXANDRIAN, (Sarane). História da literatura erótica. ed 2. Trad. Ana Maria Scherer e José Laurênio de Mello. Rio de Janeiro: Rocco, 1993.

ALMEIDA, Horácio de. Dicionário de termos eróticos e afins. $2^{\text {a }}$ ed. Rio de Janeiro: Civilização Brasileira, 1981.

ANDRADE, Adriano Guerra. Dicionário de pseudônimos e iniciais de escritores portugueses. Lisboa: Biblioteca Nacional, 2000.

ANÔNIMO. Teresa Filósofa. Trad. De Maria Carlota Carvalho Gomes. Porto Alegre: L\&PM, 2000 (Coleção Pocket L\&PM).

ARETINO, Pietro. Sonetos luxuriosos. Tradução, nota biográfica, ensaio crítico e notas de José Paulo Paes. São Paulo: Companhia das Letras, 2011. 
AZEVEDO, Natanael Duarte de; FERREIRA JÚNIOR, José Temístocles. Linguística, psicanálise e cinema: a voz que interpela no simbólico. In: FERREIRA JÚNIOR, José Temístocles; NÓBREGA, Mônica; FLORES, Valdir (Orgs.). Revista Prolíngua. vol. 11, n. 2. João Pessoa: Editora da UFPB, 2016.

BARBOSA, Socorro de Fátima Pacífico. Literatura e periódicos no século XIX: perspectivas históricas e teóricas. Porto Alegre: Nova Prova, 2007.

BUENO, Alexei. Antologia pornográfica: de Gregório de Matos a Glauco Mattoso. Rio de Janeiro: Nova Fronteira, 2004.

CERTEAU, Michel de. A invenção do cotidiano. Artes de fazer. ed 19. Trad. Ephraim Ferreira Alves. Petrópolis: Vozes, 2012.

CHARTIER, Roger. Práticas da Leitura. Trad. Cristiane Nascimento. 5 ed. São Paulo: Estação Liberdade, 2011.

CORBIN, Alain et al (orgs.). História do corpo: 2. Da Revolução à Grande Guerra. Petrópolis, RJ: Vozes, 2008.

CORRÊA, Carlos Pinto. Perversão: trajetória de um conceito. In.: Estudos de Psicanálise. Rio de Janeiro. No 29, p. 83-88. Setembro, 2006.

DABHOIWALA, Faramerz. As origens do sexo: uma história da primeira revolução sexual. Trad. Rafael Mantovani. São Paulo: Globo, 2013. (Biblioteca Azul)

DEL PRIORI, Mary. Histórias intimas: sexualidade e erotismo na história do Brasil. São Paulo: Editora Planeta do Brasil, 2011.

DELUMEAU, Jean. O pecado e o medo: a culpabilização no ocidente (séculos 13-18). Vol. 1. Trad. de Álvaro Lorencini. Bauru, SP: EDUSC, 2003.

EL FAR, Alessandra. Páginas de Sensação: Literatura popular e pornográfica no Rio de Janeiro (1870-1924). São Paulo: Companhia das Letras, 2004.

. "Crítica social e idéias médicas nos excessos do desejo: uma análise dos "romances para homens" de finais do século XIX e início do XX". In: Cadernos Pagu, n. 28, jan-jun, 2007, pp. 285-312.

FACCHINETTI, Cristiana et al. "As insanas do Hospício Nacional de Alienados (19001939)". In: História, Ciências, Saúde - Manguinhos. Rio de Janeiro, v.15, suplemento, PP. 231-242, 2008.

FOUCAULT, M. A Ordem do Discurso. São Paulo: Loyola, 1996.

FREUD, Sigmund. Três ensaios sobre a sexualidade. In.: Obras psicológicas completas de Sigmund Freud. Vol. VII. 2 ed. Rio de Janeiro: Imago, [1905]1989.

GOULEMOT, Jean-Marie. Esses livros que se lêem com uma só mão. Trad. Maria Aparecida Corrêa. São Paulo: Discurso Editorial, 2000. 
HODGART, Matthew John Caldwell. Satire: origins and principles. New Brunswick (U.S.A.) and London (U.K.): Transaction Publishers, 2010.

HUNT, Lynn. A Invenção da Pornografia: Obscenidade e as Origens da Modernidade. ed 1. São Paulo: Hedra, 1999.

MCCLINTOCK, Anne. Couro imperial: raça, gênero e sexualidade no embate colonial. Tradução de Plinio Dentzien. Campinas (SP): Editora da Unicamp, 2010.

MACKENZIE, D. F. "Bibliography and the sociology of texts". In: Bibliography and the sociology of texts. Cambridge: Cambridge University Press, 2004.

MAINGUENEAU, Dominique. O Discurso Pornográfico. Trad. Marcos Marcionilo. São Paulo: Parábola Editorial (Série Lingua[gem], n. 42), 2010.

MIRANDA, Ana. Que seja em segredo: escritos da devassidão nos conventos brasileiros e portugueses dos séculos XVII e XVIII. Porto Alegre, RS: L\&PM, 2014 (Coleção L\&PM POCKET).

MONIZ, Fábio Frohwein de Salles. Laurindo Rabelo: cadeira 26, patrono 2 ed. Rio de Janeiro: Imprensa Oficial de São Paulo, 2012. (Série Essencial, n. 9, Academia Brasileira de Letras).

MORAES, Eliane Robert. Perversos, amantes e outros trágicos. São Paulo: Iluminuras, 2013.

RABELAIS. A história de cada uma: os serões do convento. s/d [indícios de 1882].

REBELLO, Laurindo José da Silva. Obras poéticas livres. Rio de Janeiro, 1882.

ROUDINESCO, Elizabeth. A parte obscura de nós mesmos. Trad. André Telles. Rio de Janeiro: Jorge Zahar Ed., 2008.

ROUSSEAU. Jean-Jacques. As confissões. Trad. Wilson Lousada. São Paulo: Martin Claret, 2011.

SCHETTINI, Cristiana. "O que não se vê: corpos femininos nas páginas de um jornal malicioso". In: DEL PRIORI, Mary \& AMANTINO, Márcia (orgs.). História do corpo no Brasil. São Paulo: Editora UNESP, 2011.

SODRÉ, Nelson Werneck. História da imprensa no Brasil. São Paulo: INTERCOM; Porto Alegre: EDIPUCRS, 2011.

VAINFAS, Ronaldo. Trópico dos pecados: moral, sexualidade e inquisição no Brasil. ed 2. Rio de Janeiro: Civilização Brasileira, 2014.

ZILBERMAN, Regina. "Literatura de rodapé (ou) o jornal como suporte literário”. In: IDÉIAS, JORNAL DO BRASIL, 8 de novembro de 2003. Disponível em $<$ http://www2.metodista.br/unesco/hp unesco redealcar36completo.htm $>$. Acessado em 26/05/2014. 


\section{Fontes periódicas}

Coió (O). Rio de Janeiro. 1901-1902.

Rio $N u$ (O). Rio de Janeiro. 1898-1916.

Riso (O). Rio de Janeiro. 1911-1912.

RECEBIDO EM 20-05-2017

APROVADO EM 30-06-2017 